\title{
Water-soluble extract of Coleus barbatus modulates weight gain, energy utilization and lipid metabolism in secondary biliary cirrhosis: an experimental study in young rats ${ }^{1}$
}

\author{
Extrato aquoso de Coleus barbatus modula o ganho de peso, o aproveitamento \\ nutricional e o metabolismo lipídico na cirrose biliar secundária: estudo experimental \\ em ratos jovens
}

\author{
Ana Paula Ronquesel Battochio² ${ }^{2}$ Maria Salete Sartori³ ${ }^{3}$ Cláudio Antônio Rabello Coelho ${ }^{4}$ \\ 1. Study realized at the UNESP - São Paulo State University, by the Infant Hepathology Discipline, Department of Pediatrics of Botucatu \\ School of Medicine of the São Paulo State University. UNESP. \\ 2. Biologist, postgraduate student, Department of Pediatrics, Botucatu School of Medicine of the São Paulo State University. UNESP. \\ 3. Biologist, postgraduate student in Physiopathology and head of the Biochemical Laboratory, Sector of Clinical Analysis, Botucatu School \\ of Medicine of the São Paulo State University. UNESP \\ 4. Doctor Assistant Prof. and head of the Discipline of Pediatric Hepatology, Department of Pediatrics, Botucatu School of Medicine of the \\ São Paulo State University. -UNESP
}

\begin{abstract}
Purpose: To test if a water extract of Coleus barbatus (WEB) has any effect on weight gain, food energy utilization and lipid metabolism in young rats with obstructive cholestasis. Methods: Forty 21 day old (P21) Wistar rats, in groups of 10, were submitted to one of the following treatments: a sham operation with daily water or WEB administration, double ligature and resection of the bile duct with daily water or WEB administration. At P49 they were submitted for euthanasia when the following were determined: ingested feed (IF), energy utilization (EU) and weight gain (WG) from P29 to P49, together with total serum cholesterol (TC) and triacylglycerol (TG) concentrations, liver wet weight (LWW) and fat content (LFC). Two Way ANOVA and the S.N.K. test for paired comparisons were employed to study the effects of cholestasis and those of WEB and their interactions $(\mathrm{p} \leq 0.05)$. Results: Cholestasis, independently of WEB, and WEB, independently of cholestasis both reduced IF, EU, and WG, but there was no significant interaction between the two factors. Cholestasis, independently of WEB, increased LWW, LFC, the TC and TG. The WEB, independently of cholestasis, reduced these values, and there was a significant interaction between the two factors; such that these effects were more accentuated in animals with cholestasis. Conclusion: The WEB reduced IF, WG, and EU, both in the presence and absence of cholestasis in the same proportion. It also partially inhibited the increase in LWW, LFC, TC and TG caused by cholestasis. Key words: Cholestasis. Coleus barbatus. Traditional medicine. Energy utilization. Cholesterol. Triacylglycerides. Young rats.
\end{abstract}

\begin{abstract}
RESUMO
Objetivo: Testar os efeitos do extrato aquoso de Coleus barbatus (WEB) sobre o aproveitamento nutricional e o metabolismo lipídico em ratos jovens com colestase obstrutiva. Métodos: Quarenta ratos machos Wistar com 21 dias de vida (P21), em grupos de 10, foram submetidos a um dos seguintes tratamentos: operação simulada e administração diária de água ou WEB e dupla ligadura e ressecção do ducto biliar com administração diária de água ou WEB. No P49, foram sacrificados e medidos: a ração ingerida (IF), o aproveitamento nutricional (EU) e o ganho de peso (WG) desde o P29 ao P49, as concentrações séricas do colesterol total (TC) e dos triacilgliceróis (TG), o peso fresco (LWW) e o teor de gordura do fígado (LFC). A ANOVA com dois fatores e o método de S.N.K para comparações pareadas $(p \leq 0,05)$ foram utilizados para estudar os efeitos, sobre as variáveis, da colestase e do EAB e suas interações. Resultados: A colestase, independentemente do WEB, e o WEB independentemente da colestase diminuíram o WG, a IF e o EU, mas não houve interação significativa entre os dois fatores. A colestase, independentemente do WEB elevou o LWW, o LFC, o TC e os TG. O WEB, independentemente da colestase, diminuiu esses valores, havendo interação significativa entre os dois fatores, sendo estes efeitos mais acentuados nos animais com colestase. Conclusões: O EAB diminui a IF, o EU e o WG, tanto na presença quanto na ausência de colestase, na mesma proporção. O WEB inibi parcialmente o aumento do LWW, do LFC, do TC e dos TG causados pela colestase.
\end{abstract}

Descritores: Colestase. Coleus barbatus. Medicina tradicional. Aproveitamento nutricional. Triacilgliceróis. Colesterol. Ratos. 


\section{Introduction}

Atresia of the bile ducts is a serious cause of hepatobiliary disease in infancy, which presents a $100 \%$ mortality when untreated and has been the principal indication for liver transplants in children ${ }^{1}$. Ligature and resection of the bile duct in rats has been used as a model to simulate biliary atresia. However, few authors have applied this model in young rats ${ }^{2}$, which would be a more accurate biliary atresia model, as the majority of experimental studies have been performed in adult rats, where secondary infection appears to have a more important role than in young rats ${ }^{3}$. Cholestasis interferes in the feeding ${ }^{4}$, growth ${ }^{5}$ and, especially, in lipid metabolism, as shown in both clinical studies $^{6}$ and experimental models. Several mechanisms have been suggested for this interference: 1) factors that may cause anorexia, thus contributing to malnutrition secondary infections; zinc deficiency; gastroesophagic reflux due to compression of the stomach by hepatosplenomegaly and/or by ascitis; reduction of food ingestion by anorexia resulting in the increase of circulatory levels of cholecystokinin $(\mathrm{CCK})^{8}$ and of leptin ${ }^{9} ; 2$ ) reduction of the energy available for growth due to an increase in the basal metabolism ${ }^{10}$; 3) poor lipid absorption, including essential fatty acids and liposoluble vitamins, due to the absence or reduction in the concentration of bile acids in the intestine $\left.{ }^{11} ; 4\right)$ reduction in cholesterol and bile acid excretion, besides an increase in the synthesis of cholesterol, which together elevate the serum concentration of cholesterol with possible deposits in tissues ${ }^{12} ; 5$ ) reduction in the production of the growth factor similar to insulin by the liver, increasing the resistance to growth hormone (HC), which reduces protein synthesis and muscular mass, stimulates lipolysis with the loss of fat storage and a reduces the growth rate ${ }^{13} ; \mathbf{6}$ ) alterations in the storage, activation, interconversion and synthesis of metabolites due to hepatic damage ${ }^{14}$. The prevention and treatment of these nutritional alterations directly or through hepatoprotective action is very important to improve the results of liver transplant ${ }^{1}$. These considerations led us to test a possible new therapeutic resource, a plant called Coleus barbatus, of the Lamiaceae family ${ }^{15}$ (National Boldo, Brazilian Boldo or False Boldo) which is commonly used in popular Brazilian medicine in the treatment of liver problems.

The objective of the study was to test the possible effects of a water-soluble extract of Coleus barbatus on food energy utilization and lipid metabolism in young rats with secondary biliary cirrhosis obstruction of the common bile duct.

\section{Methods \\ Collection and preparation of the water-soluble extract of Boldo (WEB)}

The plant (Coleus barbatus) was collected fresh, in its natural habitat, in the district of Rubião Jr., Botucatu, during February 2000. It was identified and registered under the number BTU24169, in the Herbarium of the Botanical Department of the Biosciences Institute, UNESP - São Paulo State University, Botucatu, São Paulo. The leaves were oven-dried at $60^{\circ} \mathrm{C}$ for three days and then ground in a pestle until they constituted a fine powder. This was stored in hermetically sealed plastic flasks and labeled. The watersoluble extract was prepared by passing one liter of water at room temperature through a funnel with $60 \mathrm{~g}$ of the powder placed in filter paper. The filtrate was stored in $10 \mathrm{ml}$ amber colored glass flasks, conserved in a freezer at $-20^{\circ} \mathrm{C}$ for up to eight weeks, while thawed aliquots were maintained in a refrigerator at $-4^{\circ} \mathrm{C}$ for use in a maximum two day period.

Forty male Wistar rats were studied, born in the Pediatrics Experimental Laboratory of the Botucatu Faculty of Medicine-UNESP, of nulliparous females, weighing 180 to $220 \mathrm{~g}$ at the onset of gestation, provided by the Biotério Central of the Botucatu Campus - UNESP. From birth they were suckled in groups of six animals per dam until the $21^{\text {st }}$ day of life (P21). During this period and for the whole experimental period (P21 to $\mathrm{P} 49$ ), the animals were maintained in controlled environmental conditions - temperature between 22 to $23^{\circ} \mathrm{C}$ and a 12 hour light/dark cycle.

The experimental procedure was approved by the Ethics Commission in Animal Experimentation of Botucatu Faculty of Medicine / UNESP - São Paulo State University, protocol number 64, 25/10/1999, in accordance with the Principals of Ethics in Animal Experimentation of the Brazilian College of Animal Experimentation (COBEA) ${ }^{16}$. The maintenance of the animals and anesthetic, surgical and euthanasia procedures were performed according to the recommendations of the Canadian Council of Animal Care $(1984)^{17}$.

On P21, each animal was randomly assigned to one of the four experimental groups of 10 animals each:

SA Group: sham operation with daily administration, by gavage, of $5 \mathrm{ml}$ of water per gram of animal weight, SB Group: sham operation with daily administration, by gavage, of $5 \mathrm{ml}$ of water-soluble extract of Boldo (WEB) per gram of animal weight, LA Group: double ligature and resection of the common bile duct with daily administration, by gavage, of $5 \mathrm{ml}$ of water per gram of animal weight, LB Group: double ligature and resection of the common bile duct with daily administration, by gavage, of $5 \mu \mathrm{l}$ of WEB per gram of animal weight. All animals had ad libitum access to water and standard feed with $18 \mathrm{~g}$ of protein per $100 \mathrm{~g}$ of feed (prepared by the Pediatrics Experimental Laboratory of the Botucatu School of Medicine of the São Paulo State UniversityUNESP) (Table 1).

TABLE 1 - Feed composition (18g/100g of proteins) prepared by the Pediatrics Department Experimental Laboratory.

\begin{tabular}{ll}
\hline DIETARY COMPONENTS & g/kg \\
\hline Protein (casein) & 1.8 \\
Saline Mixture $^{18,19}$ & 0.4 \\
Fiber (corncob) $_{\text {Vitamin Mixture }}^{18}$ & 0.4 \\
Sodium Benzoate & 0.1 \\
Corn Oil & 0.01 \\
Sucrose & 0.8 \\
Cornstarch (Maizena $^{\circledR}$ ) & 1.0 \\
\hline
\end{tabular}


The ligature and resection of the common bile duct was performed according to the technique presented by Cameron and Oakley ${ }^{3}$ with modifications ${ }^{20}$. The sham operation followed exactly the same technique described above with exception of the ligatures and common bile duct resection. Euthanasia was performed on P49, beginning with an intraperitoneal injection of sodium pentobarbital (concentration of $3 \mathrm{~g} / 100 \mathrm{ml}$ of solution), at a dosage of 0.0017 $\mathrm{ml} / \mathrm{g}$ of animal weight, followed by posterior exsanguinaton. The blood and liver were collected for biochemical tests.

\section{Observations and measurements}

- Weight gain in g of the animals from P21 to P 49 using Mettler Toledo digital scales - model PB 3002, maximum weight $=3.100 \mathrm{~g}$, minimum weight $=0.5 \mathrm{~g}$, sensibility $0.1 \mathrm{~g}$.

- Total quantity of feed ingested in g, (calculated using the feed offered and the feed rejected each day) from P29 to P49, using the digital scales.

- Feed energy utilization in g of weight gain/g of ingested feed from P29 to P49

- Liver wet weight in g, using the digital scales

- Liver fat content (g of fat/100g of animal weight) by the gravimetric method extracting the fat with sulfuric ether using Soxhlet apparatus.

- Total serum cholesterol concentration in $\mathrm{mg} / \mathrm{dL}$ by the automated colorimetric enzymatic method using Technicon ${ }^{\circledR}$ equipment, model RAXT.

- Triacylglyceride serum concentration in $\mathrm{mg} / \mathrm{dL}$ by the automated colormetric enzymatic method using Technicon ${ }^{\circledR}$ equipment, model RAXT.

\section{Descriptive Statistical Methods}

The mean and standard deviation or median values of each group were calculated.

\section{Comparative Statistical Methods}

The results of each variable for the four experimental groups, were compared among themselves using the Sigma Stat program for Windows ${ }^{\odot}$ 2.0, Jandel Corporation, according to the following stages:

1) verification of the normality and equality of variances of the values obtained from each group;

2) if these conditions were satisfied, two way analysis of variance was applied, where one factor was the administration or non-administration of WEB and the other the presence (double ligature and common bile duct resection) or absence of cholestasis (sham operation). This way, the effects of each factor were tested independent of the effect of the other, as well as the interaction between both factors;

3) when significant interaction between factors was found $(p \leq 0.05)$, multiple paired comparisons were performed using the Student-Newman-Keuls (S.N.K.) method, identifying pairs of groups with significant differences among them ( $\mathrm{p}$ of $\mathrm{a} \leq 0.05$ );

4) if the group measurements did not satisfy the criteria of item 1, mathematical transformations were performed, where the chosen formula satisfied the criteria of normality and equality of variance. This was the case for weight gain and energy utilization, substituted for their rank number.

The tables present the mean and standard deviation values of the variables that did not undergo transformation and the median of those values for which transformation was necessary. The graphs show the means (solid points), the standard deviations above and below the mean (lines) and the individual values (hollow points) of the measurements, or their transformations, performed on each experimental group

\section{Results}

1) Weight gain (WG), total quantity of ingested feed (IF) and feed energy utilization (EU).

Cholestasis, independent of the effect of WEB, was associated with a statistically significant reduction in WG $\mathrm{p} \leq 0.001)$; in IF ( $\mathrm{p} \leq 0.001)$; and in $\mathrm{EU}(\mathrm{p}=0.005)$. WEB was associated with a statistically significant reduction in WG ( $p=0.003)$; in IF ( $\mathrm{p} \leq 0.001)$; and in EU ( $p=0.035)$ independent of the presence of cholestasis. There was no significant interaction between the administration of WEB and cholestasis in relation to WG $(p=0.116)$, IF $(p=0.173)$ and EU ( $p=0.330)$, see Figure 1 and Table 2 .

2) Liver wet weight (LWW) and liver fat content (LFC).

Cholestasis, independent of the effect of WEB, was associated with a statistically significant increase in LWW ( $\mathrm{p} \leq 0.001)$ and LFC ( $\leq 0.001)$. WEB was associated with a statistically significant decrease in LWW ( $\mathrm{p} \leq 0.001)$ and LFC ( $\mathrm{p} \leq 0.001)$, independent of cholestasis. WEB diminished the significant increase in LWW $(p \leq 0.001)$ and LFC $(p \leq 0.225)$ in the animals with cholestasis $(\mathrm{LB}<\mathrm{LA})$. WEB also diminished the significant increase in $\operatorname{LFC}(\mathrm{p}=0.225)$ in the animals without cholestasis $(\mathrm{SA}<\mathrm{SB})$, see Figure 2 and Table 3.

3) Serum concentration of total cholesterol (TC) and triacylglycerides (TG)

Cholestasis, independent of the effect of WEB, was associated with a statistically significant increase in the serum concentration of TC $(p \leq 0.001)$ and TG $(p \leq 0.001)$. WEB was associated with a statistically significant decrease in the serum concentration of TC $(\mathrm{p} \leq 0.001)$ and $\mathrm{TG}(\mathrm{p} \leq 0.001)$, independent of cholestasis. WEB diminished the significant increase in TC $(p \leq 0.001)$ and TG $(p \leq 0.001)$ as much in the animals without cholestasis $(\mathrm{SA}<\mathrm{SB})$ as in those without $(\mathrm{LB}<\mathrm{LA})$, see Figure 3 and Table 4. 


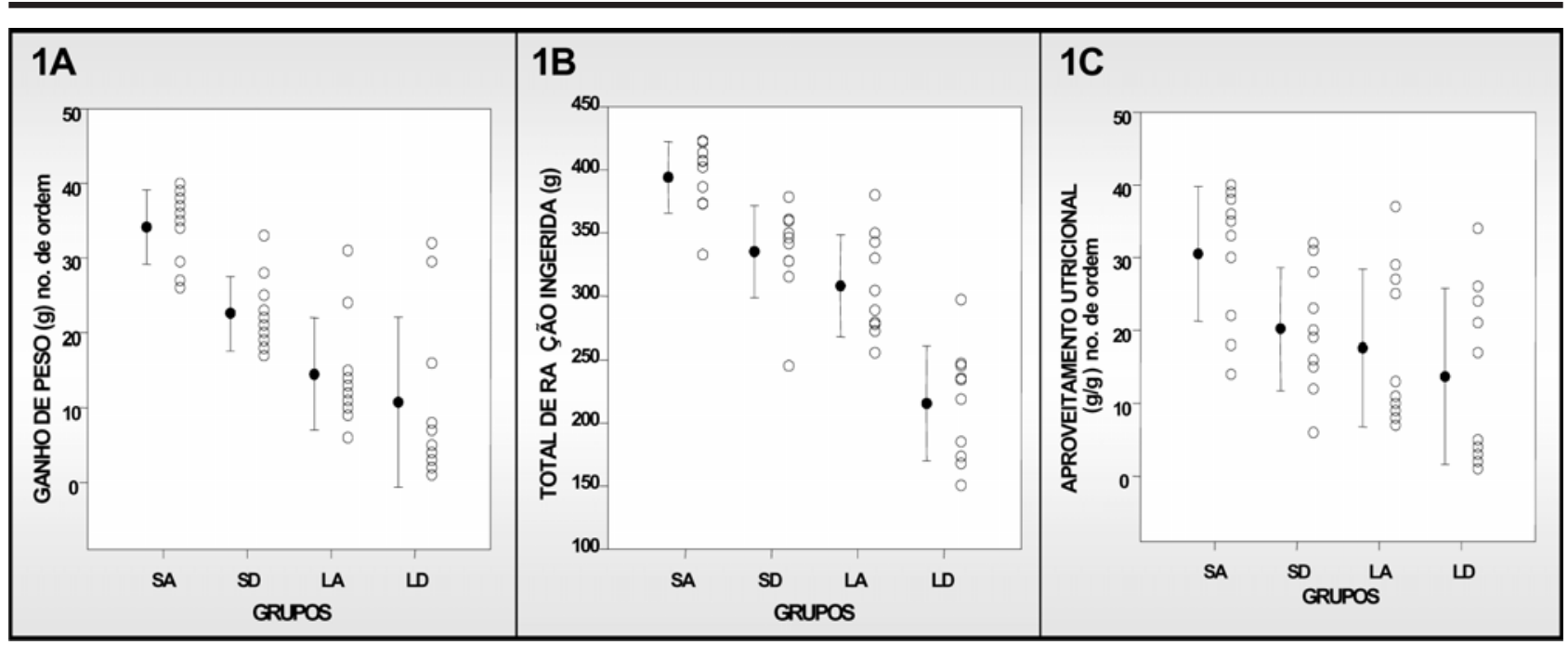

FIGURE 1 - Means, standard deviations and individual values of Weight gain (g) (1A), Total ingested feed (g) (1B) and Feed energy utilization (g/g) (1C) in rats from P29 to P49, in groups of 10, submitted to one of the following treatments: SA: sham operation with daily administration of water; SB: sham operation with daily administration of WEB; LA: double ligature with common bile duct resection with daily administration of water; LB: double ligature with common bile duct resection with daily administration of WEB.

TABLE 2 - Weight gain, total ingested feed and feed energy utilization from P29 to P49 in young rats comparisons between effects of cholestasis and of WEB, interaction between these effects and descriptive analysis.

\begin{tabular}{lllll}
\hline Variables & \multicolumn{1}{c}{$\mathbf{A}$} & \multicolumn{1}{c}{ B } & \multicolumn{1}{c}{ C } & \multicolumn{1}{c}{ D } \\
\hline Weight gain & $(\mathrm{LA}+\mathrm{LB})<(\mathrm{SA}+\mathrm{SB})$ & $(\mathrm{SA}+\mathrm{LA})>(\mathrm{SB}+\mathrm{LB})$ & $\mathrm{p}=0,116$ & Medians \\
$\begin{array}{l}\text { P29-P49 } \\
\text { (g) }\end{array}$ & $\mathrm{p} \leq 0,001$ & $\mathrm{p}=0,003$ & $\therefore$ n.s. & $\mathrm{SA}=135,99$ \\
& significant & significant & & $\mathrm{SB}=108,64$ \\
& & & & $\mathrm{LA}=94,62$ \\
& & & & $\mathrm{LB}=71,83$ \\
\hline Total of & $(\mathrm{LA}+\mathrm{LB})<(\mathrm{SA}+\mathrm{SB})$ & $(\mathrm{SA}+\mathrm{LA})>(\mathrm{SB}+\mathrm{LB})$ & $\mathrm{p}=0,173$ & Means $\pm \mathrm{SD}$ \\
ingested feed & $\mathrm{p} \leq 0,001$ & $\mathrm{p} \leq 0,001$ & $\therefore$ n.s. & $\mathrm{SA}=394,10 \pm 28,11$ \\
P29-P49 & significant & significant & & $\mathrm{SB}=335,21 \pm 36,60$ \\
(g) & & & & $\mathrm{LA}=308,04 \pm 40,52$ \\
& & & & $\mathrm{LB}=215,59 \pm 45,35$ \\
\hline Feed energy & $(\mathrm{LA}+\mathrm{LB})<(\mathrm{SA}+\mathrm{SB})$ & $(\mathrm{SA}+\mathrm{LA})>(\mathrm{SB}+\mathrm{LB})$ & $\mathrm{p}=0,330$ & $\mathrm{Medians}$ \\
utilization from & $\mathrm{p}=0,005$ & $\mathrm{p}=0,035$ & $\therefore$ n.s. & $\mathrm{SA}=0,3392$ \\
P29-P49 & significant & significant & & $\mathrm{SB}=0,3108$ \\
(g/g) & & & & $\mathrm{LA}=0,2987$ \\
& & & & $\mathrm{LB}=0,2773$ \\
\hline
\end{tabular}

$\mathbf{A}=$ Effects of the procedure, cholestasis or absence, independent of the administration or nonadministration of WEB; $\mathbf{B}=$ Effects of WEB, administration or non-administration of WEB, independent of the procedure: cholestasis or absence; $\mathbf{C}=$ Interaction and multiple comparison using S.N.K; $\mathbf{D}=$ Descriptive analysis; $\mathbf{S D}=$ Standard deviation: $\mathbf{s}$ = significant; n.s. = non-significant; SA = sham operation with administration of distilled water; $\mathbf{S B}=$ sham operation with administration of WEB; $\mathbf{L A}=$ double ligature with common bile duct resection with administration of distilled water; $\mathbf{L B}=$ double ligature with common bile duct resection with administration of WEB; $\mathbf{g}$ = grams; $\mathbf{g} / \mathbf{g}$ = grams of weight gain by grams of ingested feed. 


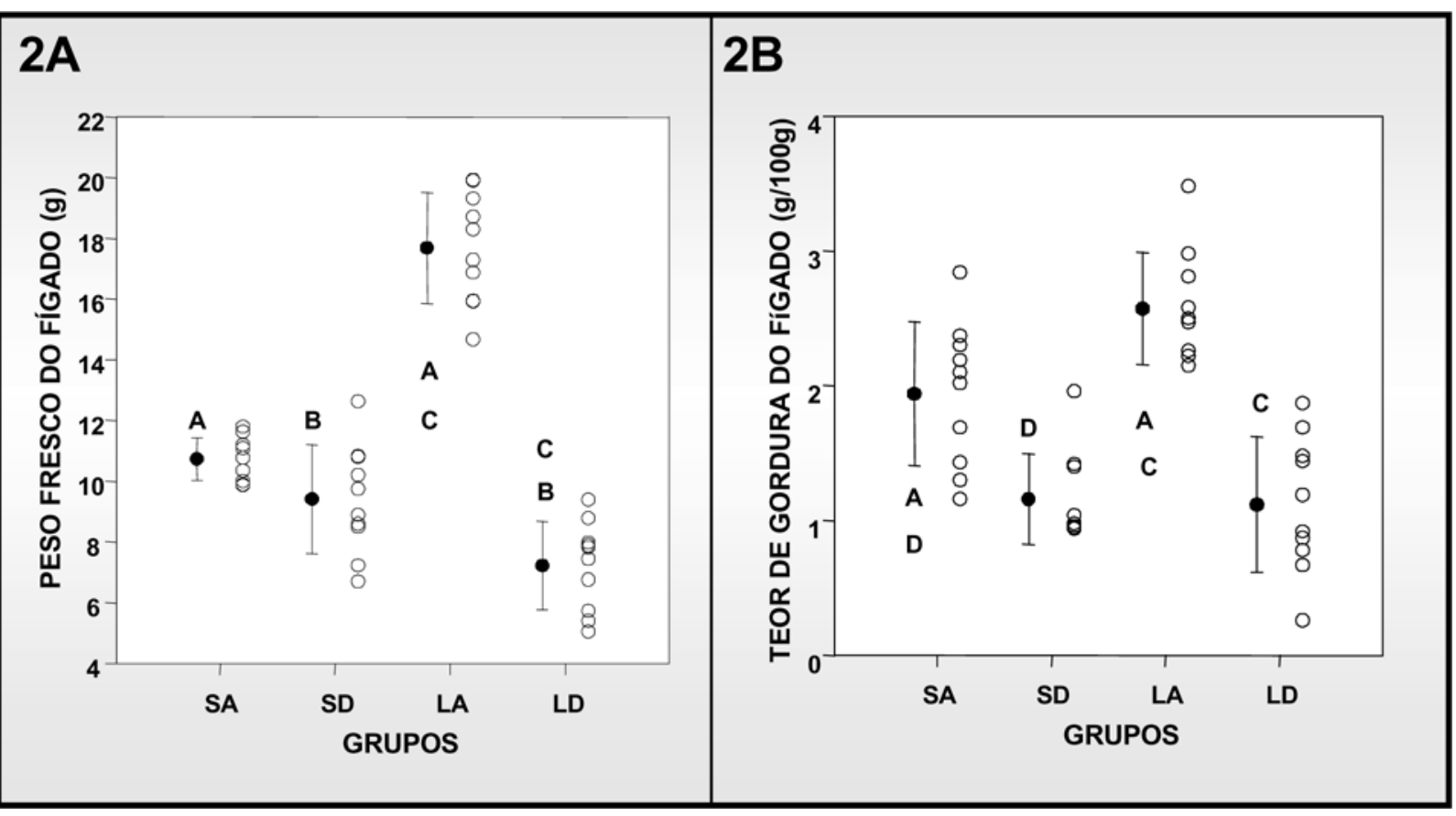

FIGURE 2 - Means, standard deviations and individual values of liver wet weight (g) (2A) and liver fat content (g/100g per animal) (2B) in rats, in groups of 10, submitted to one of the following treatments: SA: sham operation with daily administration of water; SB: sham operation with daily administration of WEB; LA: double ligature with common bile duct resection with daily administration of water; LB: double ligature with common bile duct resection with daily administration of WEB. Letters repeated in figures $2 \mathrm{~A}$ and $2 \mathrm{~B}$, of the graphs, indicate the group pairs with significant differences among them in the S.N.K. test $(p<0.05): A=S A>S B$; $\mathbf{B}=\mathrm{LA}>\mathrm{SA} ; \mathbf{C}=\mathrm{LB}>\mathrm{SB} ; \mathbf{D}=\mathrm{LA}>\mathrm{LB}$.

TABLE 3 - Liver wet weight and liver fat content in young rats - comparisons between the effects of the cholestasis and WEB, interaction between these effects and the descriptive analysis.

\begin{tabular}{|c|c|c|c|c|}
\hline Variáveis & A & B & C & D \\
\hline $\begin{array}{l}\text { Liver wet } \\
\text { weight } \\
\text { (g) }\end{array}$ & $\begin{array}{l}(\mathrm{LA}+\mathrm{LB})>(\mathrm{SA}+\mathrm{SB}) \\
\mathrm{pd} \leq 0.001 \\
\text { significant }\end{array}$ & $\begin{array}{l}(\mathrm{SA}+\mathrm{LA})>(\mathrm{SB}+\mathrm{LB}) \\
\mathrm{pd} \leq 0.001 \\
\text { significant }\end{array}$ & $\begin{array}{l}\mathrm{pd} \leq 0.001 \\
\text { significant } \\
\mathrm{LA}>\mathrm{LB} \mathrm{p}<0.05 \mathrm{~s} . \\
\mathrm{LA}>\mathrm{SA} \mathrm{p}<0.05 \mathrm{~s} \\
\mathrm{LB}<\mathrm{SB} \mathrm{p}<0.05 \mathrm{~s} . \\
\text { SAH”SB } \mathrm{p}<0.05 \text { n.s. }\end{array}$ & $\begin{array}{l}\text { Mean } \pm \text { SD } \\
\text { SA }=10.74 \pm 0.70 \\
\text { SB }=9.41 \pm 1.79 \\
\text { LA }=17.68 \pm 1.83 \\
\mathrm{LB}=7.22 \pm 1.45\end{array}$ \\
\hline $\begin{array}{l}\text { Liver fat } \\
\text { content } \\
\text { (g/100g per } \\
\text { animal) }\end{array}$ & $\begin{array}{l}(\mathrm{LA}+\mathrm{LB})>(\mathrm{SA}+\mathrm{SB}) \\
\mathrm{pd} \leq 0.001 \\
\text { significant }\end{array}$ & $\begin{array}{l}(\mathrm{SA}+\mathrm{LA})>(\mathrm{SB}+\mathrm{LB}) \\
\mathrm{pd} \leq 0.001 \\
\text { significant }\end{array}$ & $\begin{array}{l}p=0.225 \\
\text { significant } \\
L A>L B p<0.05 \text { s. } \\
L A>S A p<0.05 \text { s. } \\
L B \approx S B p<0.05 \text { s. } \\
S A>S B p<0.05 \text { n.s. }\end{array}$ & $\begin{array}{l}\text { Mean } \pm \text { SD } \\
\text { SA }=1.94 \pm 0.53 \\
\text { SB }=1.16 \pm 0.34 \\
\mathrm{LA}=2.57 \pm 0.42 \\
\mathrm{LB}=1.12 \pm 0.50\end{array}$ \\
\hline
\end{tabular}

$\mathbf{A}=$ Effects of the procedure, cholestasis or absence, independent of the administration or nonadministration of WEB; $\mathbf{B}$ = Effects of WEB, administration or non-administration of WEB, independent of the procedure: cholestasis or absence; $\mathbf{C}$ = Interaction and multiple comparison using S.N.K; $\mathbf{D}=$ Descriptive analysis; SD = Standard deviation: $\mathbf{s}=$ significant; $\mathbf{n} . \mathbf{s}$. = non-significant; $\mathbf{S A}=$ sham operation with administration of distilled water; $\mathbf{S B}=$ sham operation with administration of WEB; LA = double ligature with common bile duct resection with administration of distilled water; $\mathbf{L B}=$ double ligature with common bile duct resection with administration of WEB; $\mathbf{g}$ = grams. 

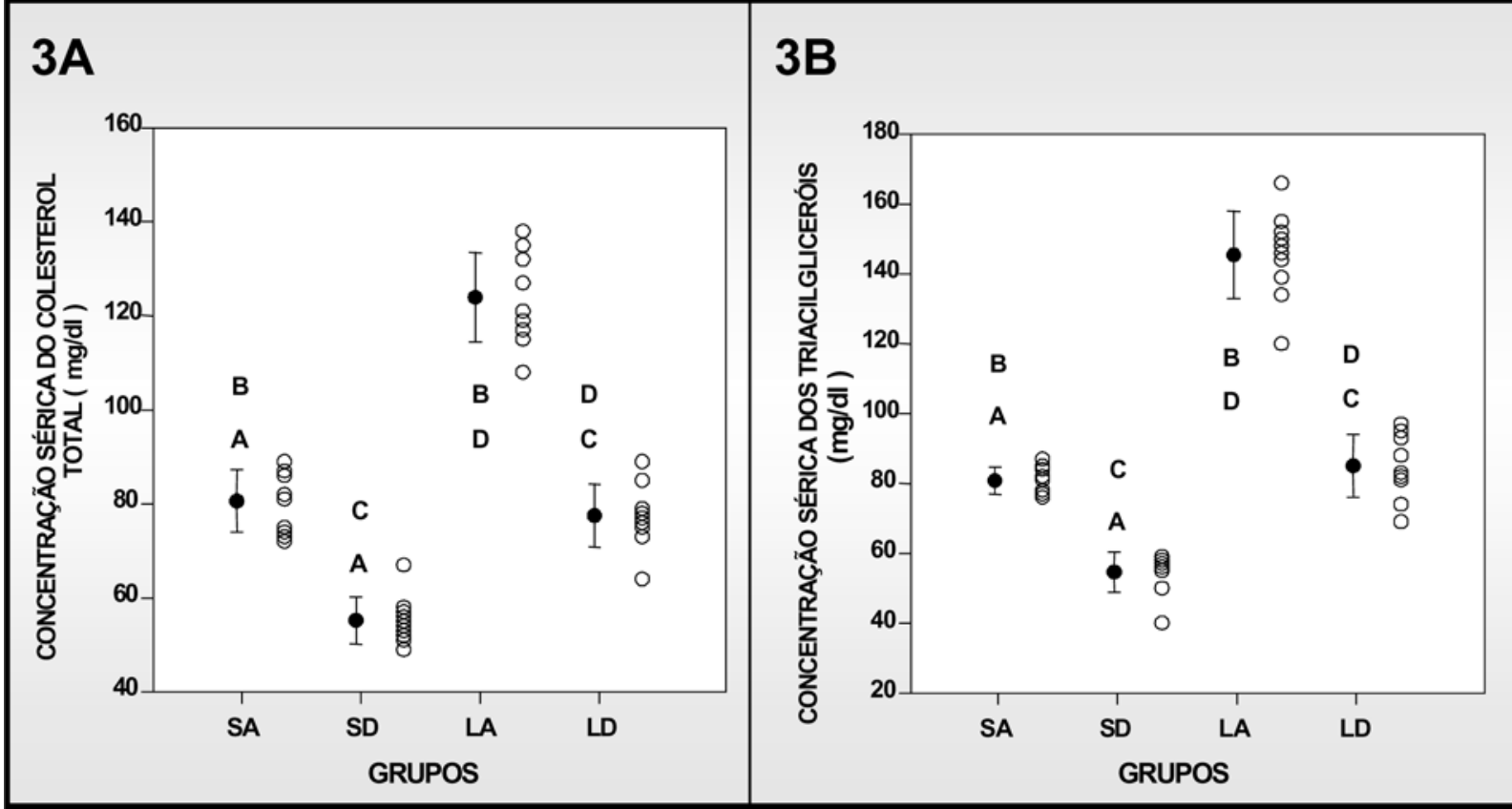

FIGURE 3 - Means, standard deviations and individual values of total serum cholesterol concentration (mg/dl) (3A) and triacylglycerides serum concentration $(\mathrm{mg} / \mathrm{dl})(\mathbf{3 B})$ in rats, in groups of 10 , submitted to one of the following treatments: SA: sham operation with daily administration of water; SB: sham operation with daily administration of WEB; LA: double ligature with common bile duct resection with daily administration of water; LB: double ligature with common bile duct resection with daily administration of WEB. Letters repeated in figures 3A and $3 B$, of the graphs, indicate the group pairs with significant differences among them in the S.N.K. test $(p<0.05)$ : $\mathbf{A}=\mathrm{SA}>\mathrm{SB} ; \mathbf{B}=\mathrm{LA}>\mathrm{SA} ; \mathbf{C}=\mathrm{LB}>\mathrm{SB} ; \mathbf{D}=\mathrm{LA}>\mathrm{LB}$.

TABLE 4 - Total serum cholesterol concentration and triacylglyceride serum concentration in young rats - comparisons between the effects of cholestasis and WEB, , interaction between these effects and the descriptive analysis.

\begin{tabular}{|c|c|c|c|c|}
\hline Variables & A & B & C & D \\
\hline $\begin{array}{l}\text { Total } \\
\text { cholesterol } \\
\text { (mg/dl) }\end{array}$ & $\begin{array}{l}(\mathrm{LA}+\mathrm{LB})>(\mathrm{SA}+\mathrm{SB}) \\
\mathrm{pd} \leq 0.001 \\
\text { significant }\end{array}$ & $\begin{array}{l}(\mathrm{SA}+\mathrm{LA})>(\mathrm{SB}+\mathrm{LB}) \\
\mathrm{pd} \leq 0.001 \\
\text { significant }\end{array}$ & $\begin{array}{l}\mathrm{pd} \leq 0.001 \\
\text { significant } \\
\mathrm{LA}>\mathrm{LB} \mathrm{p}<0.05 \mathrm{~s} \\
\mathrm{LA}>\mathrm{SA} \mathrm{p}<0.05 \mathrm{~s} \\
\mathrm{LB}>\mathrm{SB} \mathrm{p}<0.05 \mathrm{~s} \\
\mathrm{SA}>\mathrm{SB} \mathrm{p}<0.05 \mathrm{~s}\end{array}$ & $\begin{array}{l}\text { Mean } \pm \text { SD } \\
S A=80.60 \pm 6.59 \\
S B=55.20 \pm 4.98 \\
L A=123.90 \pm 9.54 \\
L B=77.50 \pm 6.70\end{array}$ \\
\hline $\begin{array}{l}\text { Triacylglycerides } \\
\text { (mg/dl) }\end{array}$ & $\begin{array}{l}(\mathrm{LA}+\mathrm{LB})>(\mathrm{SA}+\mathrm{SB}) \\
\mathrm{pd} \leq 0.001 \\
\text { significant }\end{array}$ & $\begin{array}{l}(\mathrm{SA}+\mathrm{LA})>(\mathrm{SB}+\mathrm{LB}) \\
\mathrm{pd} \leq 0.001 \\
\text { significant }\end{array}$ & $\begin{array}{l}\mathrm{pd} \leq 0.001 \\
\text { significant } \\
\mathrm{LA}>\mathrm{LB} \mathrm{p}<0.05 \mathrm{~s} \\
\mathrm{LA}>\mathrm{SA} \mathrm{p}<0.05 \mathrm{~s} \\
\mathrm{LB}>\mathrm{SB} \mathrm{p}<0.05 \mathrm{~s} \\
\mathrm{SA}>\mathrm{SB} \mathrm{p}<0.05 \mathrm{~s}\end{array}$ & $\begin{array}{l}\text { Mean } \pm \text { SD } \\
S A=80.80 \pm 3.91 \\
S B=54.60 \pm 5.76 \\
L A=145.40 \pm 12.50 \\
L B=85.00 \pm 9.02\end{array}$ \\
\hline
\end{tabular}

$\mathbf{A}=$ Effects of the procedure, cholestasis or absence, independent of the administration or nonadministration of WEB; $\mathbf{B}$ = Effects of WEB, administration or non-administration of WEB, independent of the procedure: cholestasis or absence; $\mathbf{C}$ = Interaction and multiple comparison using S.N.K; $\mathbf{D}=$ Descriptive analysis; SD = Standard deviation: $\mathbf{s}=$ significant; $\mathbf{n} . \mathbf{s}$. = non-significant; $\mathbf{S A}=$ sham operation with administration of distilled water; $\mathbf{S B}=$ sham operation with administration of WEB; $\mathbf{L A}=$ double ligature with common bile duct resection with administration of distilled water; $\mathbf{L B}=$ double ligature with common bile duct resection with administration of WEB. 


\section{Discussion}

Choice of plant under study and use of the experimental model

In spite of its popular use in the treatment of liver disturbances, there are no reports of clinical or experimental studies in the literature of the effects of Coleus barbatus. The only studies found in the literature in which the ligature and common bile duct resection model were employed in the study of natural elements were realized in adult rats to evaluate the effects of the plants Salvia miltiorrhiza ${ }^{21}$; Camellia $^{22}$ and Stephania tetrandra ${ }^{23}$.

Weight gain, total quantity of ingested feed and feed energy utilization.

Weight gain and ingested feed have been frequently used in the evaluation of the nutritional state of animals submitted to ligature of the common bile duct ${ }^{24,25}$. However, we found no references in the literature on the feed energy utilization of this model. The present study shows that cholestasis, independent of the administration or nonadministration of WEB is associated with a reduction in weight gain, ingested feed and feed energy utilization. Sokal et al. ${ }^{25}$, studied rats with obstructive cholestasis induced by ligature and common bile duct resection, and observed that from P30 to P62 a significant reduction in body weight and feed ingestion occurred, when compared to the control group with sham operation. In another study, Gouma et al..$^{24}$ evaluated adult rats weighing 285 to $320 \mathrm{~g}$ submitted to double ligature of the common bile duct, and concluded that they presented a reduction in feed ingestion.

However, animals that received administration of daily doses of WEB throughout the study, independent of cholestasis, presented a reduction in weight gain, in feed ingestion and energy utilization. These results are in accordance with the study by Almeida et al. ${ }^{26}$, who administered Coleus barbatus extract at a dosage of $880 \mathrm{mg} /$ Kg per day to pregnant rats, in the post embryo implant period, observed a reduction in weight gain and feed ingestion, though they did not study the energy utilization of these animals. The effect of Boldo (WEB) in rats with or without cholestasis was not found in the literature and could be useful in the treatment of obesity if confirmed in intact obese rats, without sham operation, but it could be prejudicial in the treatment of cholestasis. It should be emphasized that the effect of WEB acted in the same in rats with or without cholestasis, which indicates that cholestasis has no influence on this effect.

\section{Liver wet weight and fat content}

Cholestasis increased liver wet weight, reflecting the disposition of connective tissue to the formation of regenerative nodules and ductal proliferation ${ }^{27}$. The administration of WEB produced an accentuated reduction in liver weight with cholestasis to levels inferior to those found in rats without cholestasis and receiving WEB. This finding suggests a hepatoprotective action reducing hepatocytic necrosis and the consequent fibrosis and nodular regeneration. This possible action will form the objective of another publication.

We were also able to observe an increase in liver fat content in the presence of cholestasis, a finding not encountered in the literature. This increase was entirely neutralized by the administration of WEB, which may have interfered in the synthesis and mobilization of liver fat in cholestasis.

Total serum cholesterol and triacylglycerides serum concentrations.

Ligature and common bile duct resection can be used as a model of the alterations of cholesterol metabolism in biliary atresia ${ }^{28}$. Cholestasis increased the serum levels of total cholesterol and triacylglycerides, which is in accordance with the literature ${ }^{8}$. Cooper and Ockner ${ }^{29}$ showed that adult rats with selective obstruction of the bile duct presented an increase in the synthesis of cholesterol by the obstructed lobule.

WEB reduced the levels of cholesterol and triacylglycerides in the absence, as well as in the presence, of cholestasis, though this effect was more accentuated in the presence of cholestasis than in the non-cholestatic control animals. In the literature, there are no reports on the effects of Boldo (WEB) which could confirm the evidence of the hepatoprotective action cited above. As the reduction of the serum levels of cholesterol occurred in animals with ligature of the common bile duct we suggest that the increase in cholesterol synthesis is the most significant factor in hypercholesterolemia of cholestasis, rather than the cessation of bile secretion of cholesterol and bile acids.

A reduction in the serum levels of cholesterol and triacylgylcerides in the control animals could suggest the application of WEB in the treatment of hypercholesterolemia and hypertriacylglycerolemia.

\section{Conclusions}

A water-soluble extract of Coleus barbatus exerts an effect on the quantity of ingested feed, feed energy utilization and weight gain, as much in the presence as in the absence of cholestasis, in the same proportion. However the effects of WEB on liver wet weight, liver fat content and the serum levels of cholesterol and triacylgylcerides, were more accentuated in the presence of cholestasis.

\section{References}

1. Otte JB. History of pediatric liver transplantation. Where are we coming from? Where do we stand? Pediatr Transplant. 2002; 6:378-87.

2. Weisdorf SA, Hamel N, Pierpont ME, Bowers LD, Cerra FB. Increased dietary branched-chain amino acids do not improve growth in developing rats with chronic biliary obstruction. J Nutr. 1991; 121:1447-53.

3. Cameron GR, Oakley CL. Ligation of the common bile duct. J Pathol Bacteriol. 1932; 35:769-99.

4. Bavdekar A, Bhave S, Pandit A. Nutrition management in chronic liver disease. Indian J Pediatr. 2002; 69:427-31.

5. Lakatos PL, Bajnok E, Tornai I, Folhoffer A, Horvath A, 
Lakatos P, Szalay F. Decreased bone mineral density and gene polymorphism in primary biliary cirrhosis. Orv Hetil. 2004; 145:331-6.

6. Miettinen TA. Lipid absorption, bile acids and cholesterol metabolism in patients with chronic liver disease. Gut. 1972; 13:682-9.

7. Record CO, Alberti KG, Williamson DH. Lipid metabolism in experimental cholestasis. Biochem J. 1971; 124:56P.

8. Tangoku A, Doi R, Chowdhury P, Pasley JN, McKay DW, Rayford PL. Use of a specific cholecystokinin receptor antagonist (L-364,718) to determine the role of cholecystokinin on feeding and body weight in rats with obstructive jaundice. J Assoc Acad Minor Phys. 1992; 3:38-40.

9. Ben-Ari Z, Schafer Z, Sulkes J, Manhaim V, Tur-Kaspa R, Fainaru M. Alterations in serum leptin in chronic liver disease. Dig Dis Sci. 2002; 47:183-9.

10. McCullough JA, Raguso C. Effect of cirrhosis on energy expenditure. Am J Clin Nutr. 1999; 69:1066-8.

11. Tomar BS. Infant cholestasis - Advances in its understanding: new concepts. Acta Paediatr Taiwan. 2000; 41:6-12.

12. Nikkilä K, Miettinen TA. Serum cholesterol precursors, cholestanol, and plant sterols in primary biliary cirrhosis. Scand J Gastroenterol. 1988; 23:967-72.

13. Bucuvalas JC, Cutfield W, Horon J, Sperling MA, Heubi JE, Campaigne B, Chernausek SD. Resistance to the growth promoting and metabolic effects of hormone in children with chronic liver disease. J Pediatr. 1990; 117:397-402.

14. Bianchi L. Liver biopsy interpretation in hepatitis. Part I. Presentation of critical morphology features used in diagnosis (glossary). Pathol Res Pract. 1983, 178:2-19.

15. Teske M, Trentini MM. Herbarium. Compêndio de Fitoterapia. 3ª ed. Ed. Herbarium; 1997.

16. Comissão de Ensino do Colégio Brasileiro de Experimentação Animal (COBEA) - Manual para técnica em bioterismo; 1996.

17. Canadian Council of Animal Care. Guide do the Care and Use of Experimental Animals. v.1 and 2. Ottawa, Ontario: Canadian Council on Animal Care; 1980-1984.

18. Lajolo FM, Campos França MH, Zucas SM. Importância da cor da ração no consumo da mesma por ratos (Ratus norvegicus var albinus). Rev Fac Farm Bioquim. 1969; 7:95-103.

19. Fox MRS, Briggs, GM. Salt mixtures for purifield type diets III - Na improved salt mixtures for chicks. J Nutr. 1960; 72:242-50,.
20. Battochio APR, Santos AG, Silva CRM, Santos AR, Coelho CAR. Adaptação do modelo experimental de colestase extra-hepática em ratos jovens. Acta Cir Bras. 2004; 19:70-3.

21. Oh SH, Nan JX, Sohn DW, Kim YC, Lee BH. Salvia miltiorrhiza inhibits biliary obstruction-induced hepatocyte apoptosis by cytoplasmic sequestration of p53. Toxicol Appl Pharmacol. 2002; 182:27-33.

22. Zhong Z, Froh M, Lehnert M, Schoonhoven R, Yang L, Lind H, Lemasters JJ, Thurman RG. Polyphenols from Camellia sinenesis attenuate experimental cholestasisinduced liver fibrosis in rats. Am J Physiol Gastrointest Liver Physiol. 2003; 285:1004-13.

23. Park PH, Nan JX, Park EJ, Kang HC, Kim JY, Ko G, Sohn DH. Effect of tetrandrine on experimental hepatic fibrosis induced by bile duct ligation and scission in rats. Pharmacol Toxicol. 2000; 87:261-8.

24. Gouma DJ, Roughneen PT, Kumar S, Moody FG, Rowlands BJ. Changes in nutritional status associated with obstructive jaundice and biliary drainage in rats. Am J Clin Nutr. 1986; 44:362-9.

25. Sokal EM, Baudoux MC, Collette E, Hausleithner V, Lambotte L, Buts JP. Branched chain amino acids improve body composition and nitrogen balance in a rat model of extra hepatic biliary atresia. Pediatr Res. 1996; 40:66-71.

26. Almeida FCG, Lemonica IP. The toxics effects of Coleus barbatus $\mathrm{B}$. on the different periods of pregnancy in rats. J Ethnopharmacol. 2000; 73:53-60.

27. Wasser S, Tan CE. Experimental models of hepatic fibrosis in the rat. Ann Acad Med Singapore. 1999; 28:109-11.

28. De Vriese SR, Savelii JL, Poisson JP, Narce M, Kerremans I, Lefebvre R, Dhooge WS, De Greyt W, Christophe AB. Fat absorption and metabolism in bile duct ligated rats. Ann Nutr Metab. 2001; 45:209-16.

29. Cooper AD, Ockner RK. Studies of hepatic cholesterol synthesis in experimental acute biliary obstruction. Gastroenterology. 1974; 66:586-95.

\section{Acknowledgements}

We are grateful to the Conselho Nacional de Desenvolvimento Científico e Tecnológico (CNPq) for the grant received (Process no. 140556/02-8), which allowed for the realization of this work.

\section{Correspondence:}

Ana Paula Ronquesel Battochio

Rua José Dal Farra, 1103

18603-790 Botucatú - SP Brazil

apbattochio@ig.com.br
Conflict of interest: none Financial source: none

Received: January 27, 2005

Review: February 23, 2005

Accepted: March 15, 2005

\section{How to cite this article:}

Battochio APR, Sartori MS, Coelho CAR. Water-soluble extract of Coleus barbatus modulates weight gain, energy utilization and lipid metabolism in secondary biliary cirrhosis: an experimental study in young rats. Acta Cir Bras. [serial online] 2005 May-June;20(3). Available from URL: http://www.scielo.br/acb 